\title{
電位差滴定法による水酸化マグネシウム難燃剤の表面状態の評価
}

\author{
松井 誠 ${ }^{a}$, 田里伊佐雄 ${ }^{b}$ \\ $a$ 神島化学工業株式会社（テ769-1103 香川県三豊郡詫間町大字香田 80 番地） \\ b 岡山大学工学部（干700-8530 岡山市津島中 3-1-1）

\section{Evaluation of Surface State of Magnesium Hydroxide as Flame Retarder by Potentiometric Titration Method}

\begin{abstract}
Seiji MATSUI ${ }^{\mathrm{a}}$ and Isao TARI ${ }^{\mathrm{b}}$
${ }^{a}$ Konoshima Chemical, Research Institute of Technology (Koda 80, Takuma-cho, Mitoyo-gun, Kagawa 769-1103, Japan) ${ }^{b}$ Faculty of Engineering, Okayama University (3-1-1 Tsushima-naka, Okayama 700-8530, Japan)

Received July 1, 2002 ; Accepted September 3, 2002

Magnesium hydroxide powder for flame retarder of plastics must have hydrophobic property for providing good dispersion state during mixing the powder and plastics having hydrophobic property. In order to evaluate the character as a flame retarder of magnesium hydroxide powders treated with stearic acid and a silane coupling reagent, potentiometric titrations were done for dispersions consisting of the powder and aqueous solution of $\mathrm{LiClO}_{4}$ and $\mathrm{TritonX}^{-100}$ as a wetting agent. The acid-base reaction was $\mathrm{Mg}(\mathrm{OH})_{2}+2 \mathrm{HNO}_{3} \longrightarrow \mathrm{Mg}\left(\mathrm{NO}_{3}\right)_{2}+2 \mathrm{H}_{2} \mathrm{O}$ which proceeded for the powder without the surface treatment reagents in the $\mathrm{pH}$ range between 10 and 10.5. The titration curves obtained for the powders with the reagents shifted to the $\mathrm{pH}$ reagion below 10 due to inhibition of the reaction by the reagents at the powder surface. The shifting degree was greater with increase in the amounts of the reagents at the surface. The powders yielding greater shifting, viz., serious reaction inhibition were found to be excellent flame retarder, which can be easily compounded with ethylene-ethylacrylate copolymer as a covering plastic for electric wire under lower torque of mixing machine to provide composites having better characteristics on elongation, tensile strength and electrical resistance per unit volume as the physical poroperties. The potentiometric titration method used was found to be very useful for evaluation of the magnesium hydroxide powder for flame retarder.
\end{abstract}

Key Words : Magnesium Hydroxide, Flame Retarder, Plastic, Surface Treatment, Potentiometric Titration

\section{1 緒 言}

プラスチックには燃えやすい性質のものが多く，用途によ っては,このような性質に基づく火災事故の防止は重要問題 である、従来，電線被覆用プラスチックの難燃化は，ポリ塩 化ビニル系プラスチックを使用したり，ポリオレフィン系プ ラスチックへ有機ハロゲン化物系難燃剤を添加することが主 流であった。しかし，焼却時におけるダイオキシンの発生や リサイクルなどの環境問題が深刻になるにつれ, 脱塩化ビニ ルの動きが活発となり，主にポリオレフィン系プラスチック が使われるようになり，難燃剤としては，ノンハロゲン難燃 剤の検討が主流となっている，ノンハロゲン難燃剤としては 主に水酸化マグネシウムが注目され，一部の電線被覆用途に 使用されてきた。加えて, 上記の環境問題の深刻化による影 響で, 最近は, 建物・家電製品・自動車などの電線の被覆材 のみならず壁紙や建材, 家電製品のハウジング材にも, 水酸 化マグネシウムを使用する検討が進んでいる ${ }^{1-6)}$.

水酸化マグネシウムは, 脱水反応時の吸熱作用で難然性を 発揮するため, 例えば，水酸化マグネシウム粉末重量をポリ オレフィン系プラスチック重量で割って得られる重量比が 1 以上になるよう，水酸化マグネシウム粉末をポリオレフィン 系プラスチックに充填しないと，充分な難燃性が得られない.
しかし, 水酸化マグネシウム粒子表面は親水性なので疎水 性プラスチックに大量に混練することは難しく，また無理に 混練するとプラスチックの加工性, 成形品外観, 機械的物性, 耐水性などの物性低下は避けられない7). 従って, 脂肪酸や シランカップリング剤などで表面処理し，水酸化マグネシウ 么粉末の表面を踈水化することで，プラスチックへの分散性 を向上させ，難燃性を賦与してもプラスチックの物性を低下 させない試みが従来から行われてきた ${ }^{8,9}$.

前記した疎水化処理水酸化マグネシウム粉末を混練すると, プラスチックの物性が低下することは避けられないが，低下 の程度が表面踈水化処理により大きく変わるという問題があ る。この原因として，表面処理剤による被覆が不均一であり， 粒子表面に注目すると水酸化マグネシウム自体が露出してい ることが考えられる.しかし, 水酸化マグネシウム粉末の表 面被覆状態を正確に評価する方法は知られていないのが現状 である、本研究では, 水酸化マグネシウム系難燃剂粉末の表 面被覆状態を電位差滴定法で定量的に調べることを検討し, ポリオレフィン系プラスチックへの分散性や混練したプラス チックの耐水性評価に電位差滴定法を応用できる可能性を調 ベた. 


\section{2 実験方法}

\section{1 水酸化マグネシウム粉末の表面処理}

水酸化マグネシウム粉末は, 合成物で, Fig. 1 の SEM 走 查電子顕微鏡写真から分かるように，一次粒子が数ミクロン からサブミクロンで二次凝集度合いの低いもの（以後非凝集 型粒子と表記）と，次粒子はサブミタロン $(0.1 \sim 0.5 \mu \mathrm{m})$ と小さいが凝集しており, 凝集体の平均粒子径が $4.2 \mu \mathrm{m}$ (以後凝集型粒子と表記）のものを使用した。

2. 1.1 ステアリン酸での湿式および乾式表面処理 ス テアリン酸の表面処理量を変化させるための湿式処理は, 水 酸化マグネシウム粉末の水䀣濁液（水：1000 g, 粉末 $200 \mathrm{~g}$, 粉末濃度 $3.4 \mathrm{~mol} \mathrm{dm}^{-3}$, 温度 $80^{\circ} \mathrm{C}$ ）に対し，攪拌下でステ アリン酸ナトリウム水溶液（濃度 $0.16 \mathrm{~mol} \mathrm{dm}^{-3}$, 温度 80 $\left.{ }^{\circ} \mathrm{C}\right)$ を，ステアリン酸処理量が水酸化マグネシウム $1.0 \mathrm{~g}$ $(0.017 \mathrm{~mol})$ に対して $5.6 \times 10^{-6}, 2.2 \times 10^{-5}, 9.7 \times 10^{-5}, 1.1$ $\times 10^{-4} \mathrm{~mol}$ となるように, 添加するステアリン酸ナトリウ 厶水溶液の容量を変えてそれぞれ添加し, その後 3 時間攪拌 してろ過し, $100^{\circ} \mathrm{C} て ゙ 24$ 時間乾燥後, 粉砕してそれぞれの 試料を得た。ステアリン酸ナトリウムを用いて処理をしたが， この処理もステアリン酸処理と記すことにする.

乾式処理は, 水酸化マグネシウム粉末 $1.0 \mathrm{~g}$ に対してステ アリン酸が $1.0 \times 10^{-4} \mathrm{~mol}$ の割合になるよう配合し，ヘンシ エルミキサー中に入れ, 約 $100^{\circ} \mathrm{C}$ まで加温し, 30 分間高速 擋汼して行った.

2. 1.2 シランカップリング剤での湿式表面処理水酸 化マグネシウム粉末の水懸濁液（粉末濃度 $3.4 \mathrm{~mol} \mathrm{dm}^{-3}$, 温度約 25 C) に，䝫酸で $\mathrm{pH}$ を約 3.0 に調整した $0.035 \mathrm{~mol}$ $\mathrm{dm}^{-3}$ 濃度の $\gamma$-メタクリロキシプロピルトリメトキシシラン (以後 $\gamma$-MPTMS と表記) を, 水酸化マグネシウム粉末 1.0 $\mathrm{g}$ に対して $\gamma$-MPTMSが $4.0 \times 10^{-5} \mathrm{~mol}$ となるように添加 した。添加後 24 時間懸濁液を攪抖してから固形分をろ過し, 乾燥機中 $80^{\circ} \mathrm{C}$ で 24 時間乾燥した。 その後，100，150, 200, $250^{\circ} \mathrm{C}$ で各々 1 時間熱処理し，粉砕して試料を得た。

\section{2 粉末分析}

末処理の水酸化マグネシウム粉末については，比表面積を BET 法 (日機装 (株) 製： $\beta$ sorb Model 4200) で, 平均粒子 径を粒度分布計 (日機装(株)製：MICROTRAC HRA Model 9320-X100）で測定し，粒子像を走査電子顕微鏡（日 立製作所 (株) 製：S-2360N, 以後 SEM と表記) で観察した。

表面処理した水酸化マグネシウム粉末については, 粉末 $1.0 \mathrm{~g}$ 当りのステアリン酸および $\gamma$-MPTMS の表面処理量を $\mathrm{mol} \mathrm{g}^{-1}$ で求めた. 即ち, ステアリン酸の表面処理量は, 試 料の所定量をエ夕ノールになじませ， $6 \mathrm{~mol} \mathrm{dm}^{-3} \mathrm{HCl}$ で水 酸化マグネシウムを溶解させた後, エチルエーテルで遊離ス テアリン酸分を抽出し，エーテル層を揮発させた有機残査を 秤量することにより求めた (エーテル抽出法). 結果を Table 1 の Amount of coating 欄に示した. また, $\gamma$-MPTMS の表面処理量は, 試料の所定量を空気雲囲気 $600^{\circ} \mathrm{C} て ゙$ 焼成 し, $6 \mathrm{~mol} \mathrm{dm}^{-3} \mathrm{HCl}$ に溶解させた後, 誘導結合プラズマ 分光法 (セイコー電子工業 (株) 製：ICP-AES, SII SPS-1700 VR）で Si 值を测定して， $\gamma$-MPTMS 量に換算することによ り求めた。

\section{3 電位差滴定}

未処理および表面処理水酸化マグネシウム粉末 $1.0 \mathrm{~g}$ を, 分散剂として $1.5 \times 10^{-3} \mathrm{~mol} \mathrm{dm} \mathrm{dm}^{-3}$ 濃度のトリトン X-100
(ポリオキシエチレンオクチルフェニルエーテル，エチレン オキシドの重合度 10）を含み，また，電解質として $9.4 \times$ $10^{-3} \mathrm{~mol} \mathrm{dm^{-3 }}$ 濃度の過塩素酸リチウムを含む水溶液 100 $\mathrm{cm}^{3}$ 中に添加し，ディスパーを用いて $800 \mathrm{rpm}$ で 10 分間分 散処理して懸濁液を調製した。この懸濁液を $25^{\circ} \mathrm{C} て ゙$ 窒素ガ スをバブリングしながら，自動滴定装置（京都電子工業 (株) 製：AT-400）を用いて $0.1 \mathrm{~mol} \mathrm{dm} \mathrm{dm}^{-3} \mathrm{HNO}_{3}$ 水溶液を 0.1 $\mathrm{cm}^{3} \mathrm{~min}^{-1}$ (水酸化マグネシウム $1 \mathrm{~mol}$ に対して, 水素イオ ンとして $\left.6.0 \times 10^{-4} \mathrm{~mol} \mathrm{~min}^{-1}\right)$ の速度で滴下し，ガラス電 極を用いて温度 $25^{\circ} \mathrm{C}$ での滴定溶液中の $\mathrm{pH}$ を測定すること により滴定曲線を得た。なお，この酸一塩基反応は，

$$
\mathrm{Mg}(\mathrm{OH})_{2}+2 \mathrm{HNO}_{3} \longrightarrow \mathrm{Mg}\left(\mathrm{NO}_{3}\right)_{2}+2 \mathrm{H}_{2} \mathrm{O}
$$

であり，粉末表面の処理剤は，この反応を妨害する形で滴定 曲線に反映されると考えている.

\section{4 ポリオレフィンへの溶融混練試験およびプラスチック 物性の測定}

2. 4. 1 溶融混練試験吕リオレフィンとしてエチルア クリレート含有量 15 mass\%のエチレンーエチルアクリレー 卜共重合体 (以後 EEA と表記) を 50 mass\%，水酸化マグ ネシウム粉末を 50 mass\%で配合して混合した後に，東洋精 機(株)製ラボプラストミルを用いて， $150^{\circ} \mathrm{C} て ゙ 5$ 分間，回転 数 $50 \mathrm{rpm}$ で溶融混練して, 混練の際の定常トルクを測定し た．定常トルクは，EEAへの水酸化マグネシウム粉末の混 合 (分散) 状態を反映し、トルクが大きいと分散が悪いと判 断し，小さいと分散が良いと判断する。調製した混練物を液 体窒素に浸して割り，破断面のSEM 観祭を行った。なお，

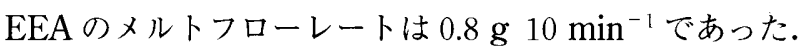

2. 4.2 引張試験 混練物を $150^{\circ} \mathrm{C}$ でプレス成形して, 厚み $2 \mathrm{~mm}$ のシートを作成し，ダンベル状に打ち抜いたも のを用いて JIS K 7113 に準拠して引張試験を行った10).

\section{4.3 体積抵抗率および耐水性試験難燃骺としての} 水酸化マグネシウム粉末を混練したプラスチックを電線被覆 に用いる場合，特に耐水性の優れたものが求められることが ある。このことに関して，優れた疎水化剤として知られてい る $\gamma$-MPTMS を用いて処理することがある.この処理を施 した水酸化マグネシウム粉末を混練したプラスチックについ て, 体積抵抗率の水分による変化を測定して耐水試験を行っ た。初期の体積抵抗率は, JIS K6911に準拠して混練物を $150^{\circ} \mathrm{C}$ でプレス成形し, 厚み $1 \mathrm{~mm} \times$ 縦 $130 \mathrm{~mm} \times$ 横 130 $\mathrm{mm}$ のシートを作成し, 温度 $30^{\circ} \mathrm{C}$, 相対湿度 $50 \%$ の雲囲気 下で 3 時間放置してから固有抵抗測定電極（横河電機(株) 製：ハイレジスタンスメーター）を用いて $500 \mathrm{~V}$ の電圧をか け, 1 分間充電した後の体積抵抗值を測定し, 体積抵抗率に 換算した ${ }^{11)}$ 。また，耐水性は，シートを $80^{\circ} \mathrm{C} に$ 加温した純 水に 96 時間浸せきさせた後, シート表面の水分を除去する 目的で $40^{\circ} \mathrm{C}, 8$ 時間シートを乾燥し, 前記と同様にして浸せ き後の体積抵抗率を求めた。

\section{3 実験結果および考察}

\section{1 水酸化マグネシウム粉末の特性}

3. 1.1 粒子性状表面処理に使用した 2 種類の合成水 酸化マグネシウム粉末の SEM 写真を Fig. 1 に示す.（1）は, SEM 写真の一次粒子径と粒度分布計で测定した平均粒子径 


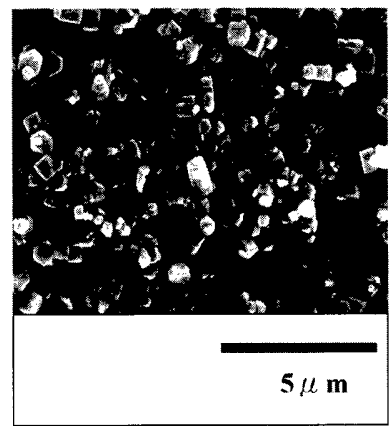

(1)

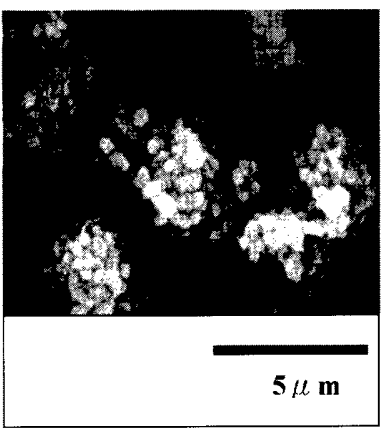

(2)
Fig. 1 Magnesium hydroxide powders. (1): Poorly aggregated particles (Specific surface area by BET method: $5.4 \mathrm{~m}^{2}$ $\mathrm{g}^{-1}$, mean particle size: $\left.0.7 \mu \mathrm{m}\right)$, (2): Highly aggregated particles (Specific surface area by BET method: $6.9 \mathrm{~m}^{2} \mathrm{~g}^{-1}$, mean particle size: $4.2 \mu \mathrm{m}$ ), The particles were formed by aggregation of small particles with sizes of $0.1 \sim 0.5 \mu \mathrm{m}$.

がほぼ一致した（約 $0.7 \mu \mathrm{m} ）$ ので, 凝集が殆ど無いと見な し, 非凝集型粒子と記す.（2）は, SEM 写真から 0.1 0.5 $\mu \mathrm{m}$ の一次粒子が凝集しているのが観察され, 二次粒子径の 大きさと粒度分布計で測定した平均粒子径がほぼ一致した （約 $4 \mu \mathrm{m} ）$ ので，凝集型粒子と記す.BET法による比表面

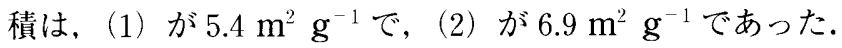
3. 1.2 ステアリン酸の表面被覆状態非凝集型および 凝集型水酸化マグネシウム粉末をステアリン酸で表面処理す る際に，1処理量，(2処埋方法(湿式法拈上び乾式法)を変 化させた。得られた試料について表面ステアリン酸の量 （E）を求めた。また，ステアリン酸を単分子層吸着と考え， 比表佰積とステアリン酸 1 分子当たりの吸着断面積から計算 で求めた吸着量を理論值 $(\mathrm{X})$ とし，Xを式（2）を用いて 計算で求めた ${ }^{22)}$. 実験値と理論值の比を見掛け表面被覆率と し，これを $(\mathrm{E} / \mathrm{X}) \times 100(\%)$ で求めた。結果をTable 1 に 宗す.

$$
\mathrm{X}=\mathrm{Y} /(\mathrm{N} \times \mathrm{C})
$$

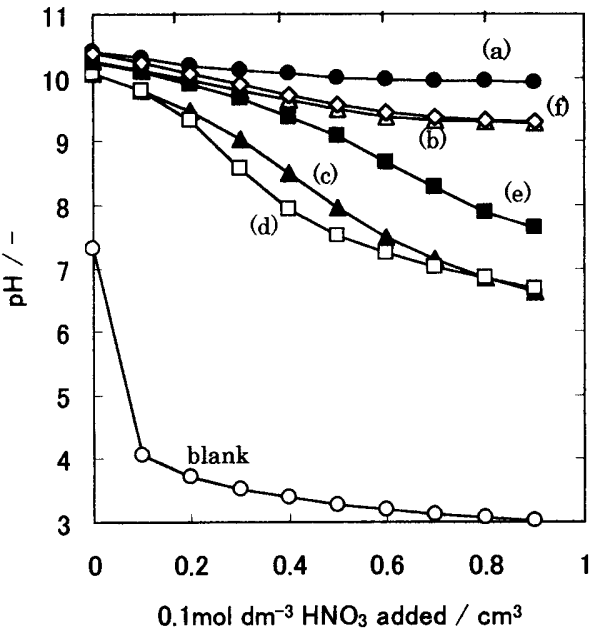

Fig. 2 Potentiometoric titration curves for $\mathrm{Mg}(\mathrm{OH})_{2}$ powder uncoated and coated by stearic acid. Powder: poorly aggregated particles $(\boldsymbol{O}, \triangle, \boldsymbol{\Delta}, \square, \boldsymbol{\square})$, highly aggregated particles $(\diamond), \bigcirc$ : blank, $\bigcirc$ : no coating. Coatings of samples (b), (c), (d) and (f) were done by wet process, while that of sample (e) was done by dry process. Amounts of stearic acid taken up by the powder were $5.6 \times 10^{-6}(\triangle), 2.2 \times 10^{-5}(\boldsymbol{A})$, $9.7 \times 10^{-5}(\square), 1.0 \times 10^{-4}(\square)$ and $1.1 \times 10^{-4} \mathrm{~mol} \mathrm{~g}^{-1}(\diamond)$.

ここで, $\mathrm{X}$ : 粒子 $1.0 \mathrm{~g}$ 当りに吸着するステアリン酸のモル 数 $\left(\mathrm{mol} \mathrm{g}^{-1}\right), \mathrm{Y}$ : 粒子の BET 比表面積 $\left(\mathrm{m}^{2} \mathrm{~g}^{-1}\right), \mathrm{C}$ : ス テアリン酸の吸着断面積 $\left(2.44 \times 10^{-19} \mathrm{~m}^{2} \text { molecule }{ }^{-1}\right)^{13)}$, $\mathrm{N}$ : アボガドロ数 $\left(6.02 \times 10^{23}\right.$ molecule mol $\left.{ }^{1}\right)$ である.

Fig. 2 は，ステアリン酸で表面処理した水酸化マグネシウ ム試料の硝酸による電位差滴定曲線である. 水酸化マグネシ ウム粉末には, 非凝集型と凝集型を表面処理剂の処理量と処 理方法を変えて処理したものを用いた，図中のブランクはブ ランク曲線を意味し，水酸化マグネシウム粉末が存在しない 溶液での滴定曲線である，水酸化マグネシウムは弱アルカリ 性であるため，水酸化マグネシウム粉末が存在する溶液の滴 定曲線はブランク曲線に比べ， $\mathrm{pH}$ が高い方にシフトした。 表面処理試料と未処理試料の滴定曲線の比較から，表面処理 試料では，粒子表面のステアリン酸が滴下硝酸と水酸化マグ

Table 1 Coating of $\mathrm{Mg}(\mathrm{OH})_{2}$ by stearic acid and physical properties of EEA/ $\mathrm{Mg}(\mathrm{OH})_{2}$ composites.

\begin{tabular}{|c|c|c|c|c|c|c|c|c|c|}
\hline \multirow[b]{3}{*}{ Sample } & & & $\mathrm{Co}$ & osition: EEA & mass $\%, \mathrm{Mg}$ & $\mathrm{OH})_{2} 50$ mass $\%$ & & & \\
\hline & \multirow[b]{2}{*}{ Particles ${ }^{1)}$} & \multirow[b]{2}{*}{$\begin{array}{l}\text { Coating } \\
\text { process }\end{array}$} & \multirow{2}{*}{$\begin{array}{c}\text { Amount of } \\
\text { coating } \\
\text { E } \\
\text { [experimental] } \\
\left(\mathrm{mol} \mathrm{g}^{-1}\right)\end{array}$} & \multirow{2}{*}{$\begin{array}{l}\text { Amount for } \\
\text { formation of } \\
\text { monolayer } \\
\text { coating } \\
\quad \mathrm{X} \\
\text { [theoretical] } \\
\left(\mathrm{mol} \mathrm{g}^{-1}\right)\end{array}$} & \multirow{2}{*}{$\begin{array}{l}\text { Apparent } \\
\text { ratio of } \\
\text { coating } \\
(\mathrm{E} / \mathrm{X}) \times 100\end{array}$} & \multicolumn{3}{|c|}{$\begin{array}{c}\text { Physical properties of } \\
\text { EEA/ } \mathrm{Mg}(\mathrm{OH})_{2} \text { composites }\end{array}$} & \multirow{2}{*}{$\begin{array}{c}\text { Solution } \mathrm{pH} \\
\text { after adding } \\
0.5 \mathrm{~cm}^{3} \text { of } \\
0.1 \mathrm{~mol} \mathrm{dm}^{-3} \mathrm{HNO}_{3} \\
\text { as a titrant }\end{array}$} \\
\hline & & & & & & $\begin{array}{l}\text { Compounding } \\
\text { torque } \\
(\mathrm{kg} \mathrm{m})\end{array}$ & $\begin{array}{c}\text { Tensile } \\
\text { strength } \\
(\mathrm{MPa})\end{array}$ & $(\%)$ & \\
\hline (a) & $\mathrm{P}$ & - & 0 & $3.7 \times 10^{-5}$ & 0 & 4.6 & 8.5 & 350 & 10.0 \\
\hline (b) & $\mathrm{P}$ & Wet & $5.6 \times 10^{-6}$ & $3.7 \times 10^{-5}$ & 15 & 4.5 & 8.4 & 510 & 9.5 \\
\hline (c) & $\mathrm{P}$ & Wet & $2.2 \times 10^{-5}$ & $3.7 \times 10^{-5}$ & 60 & 4.3 & 8.4 & 1100 & 7.9 \\
\hline (d) & $\mathrm{P}$ & Wet & $9.7 \times 10^{-5}$ & $3.7 \times 10^{-5}$ & 264 & 3.6 & 9.0 & 1240 & 7.5 \\
\hline (e) & $\mathrm{P}$ & Dry & $1.0 \times 10^{-4}$ & $3.7 \times 10^{-5}$ & 273 & 4.1 & 7.2 & 990 & 9.1 \\
\hline (f) & $\mathrm{H}$ & Wet & $1.1 \times 10^{-4}$ & $4.7 \times 10^{-5}$ & 242 & 4.8 & 8.2 & 1060 & 9.6 \\
\hline
\end{tabular}

1) P:poorly aggregated particles, H:highly aggregated particles. 
ネシウムとの反応を妨げるので，硝酸滴下による $\mathrm{pH}$ 低下の 程度が大きい. Table 1 のデー夕と併せて考察すると，(1)表 面処理量を多くするにつれ（試料 $(\mathrm{a}) \sim(\mathrm{d}))$ ，硝酸滴下によ る $\mathrm{pH}$ 低下の程度が次第に大きくなる。これは，ステアリン 酸で被覆される割合が多くなると，剥き出しの水酸化マグネ シウムの表面が少なくなり，剥き出し表面を介しての酸一塩 基中和反応が進みにくくなったためである。(2)処理剂量が充 分足りている $((\mathrm{E} / \mathrm{X}) \times 100 \approx 250 \%)$ ようにした湿式法と乾 式法調製の試料（試料（d)と（e)）では，どちらも $\mathrm{pH}$ 低下 の程度が大きいと期待されたが，予想に反して乾式法調製試 料で $\mathrm{pH}$ 低下の程度が小さかった。これは，ステアリン酸が 不均一な表面被覆状態であったことを示している。(3)非凝集 型粒子と凝集型粒子（試料 (d) と (f)) では， $(\mathrm{E} / \mathrm{X}) \times 100 \approx$ $250 \%$ ではあるが，凝集型粒子からなる試料で $\mathrm{pH}$ 低下の程 度は小さい。これは，ステアリン酸ナトリウム水溶液を用い る表面処理時にステアリン酸イオンが粒子凝集体の内側まで 入り込めず，内側粒子の被覆ができなかったこと，および滴 定時にはステアリン酸イオンに比べ滴下硝酸から生成する水 素イオンの大きさが小さいため ${ }^{14,15)}$ ，粒子凝集体内部まで入 れることを示している。

\section{2 電位差滴定評価とプラスチック物性との関係}

3. 2. 1 混練トルク, 引張強度および伸びとの関係

3.1.2 で電位差滴定評価したステアリン酸表面処理試料をエ チレンーエチルアクリレート共重合体（EEA）に溶融混練

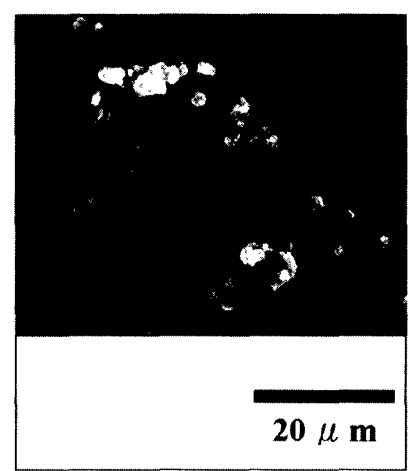

Sample (a)

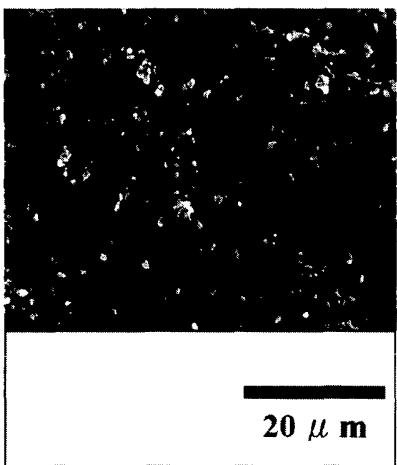

Sample (d)

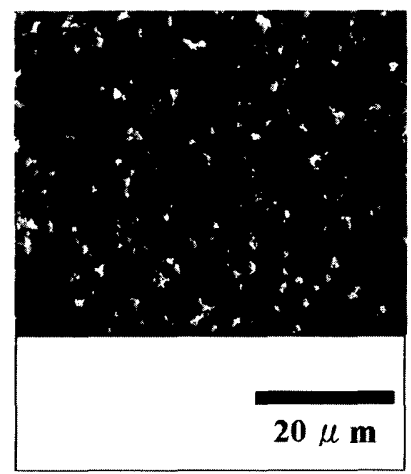

Sample (b)

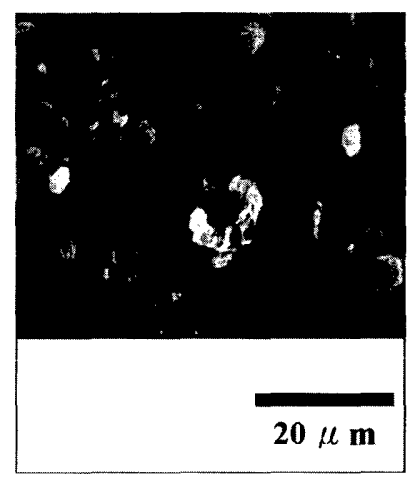

Sample (f)
Fig. 3 SEM micrographs of mechanically fractured surfaces of EEA $\mathrm{Mg}(\mathrm{OH})_{2}$ composites. The powders of Sample (a), (b) and (d) were poorly aggregated particles, while that of Sample (d) was highly aggregated particles. The amount of stearic acid taken up by the powders were zero (Sample (a)), $5.6 \times 10^{-6} \mathrm{~mol} \mathrm{~g}^{-1}$ (Sample (b)), $9.7 \times 10^{-5} \mathrm{~mol} \mathrm{~g}^{-1}$ (Sample (d)) and $1.1 \times 10^{-4} \mathrm{~mol} \mathrm{~g}^{-1}$ (Sample (f)).

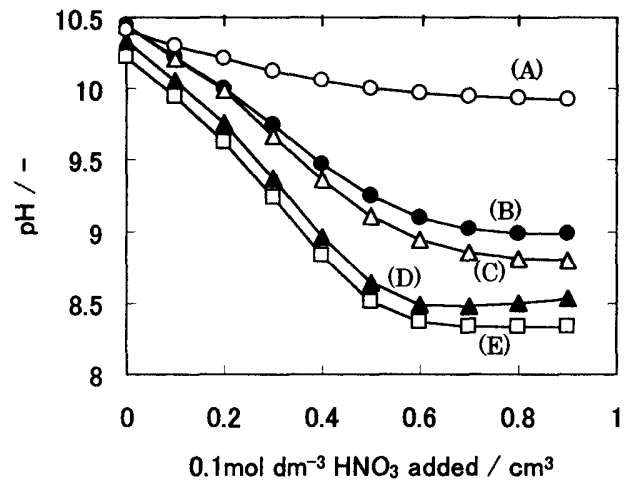

Fig. 4 Influence of heat treatment temperature on potentiometric titration curves of poorly aggregated $\mathrm{Mg}(\mathrm{OH})_{2}$ powder coated with $\gamma$-MPTMS. $\bigcirc$ : (A) no coating. Heat treatment temperature, $200^{\circ} \mathrm{C}, \square$ : (E) $250^{\circ} \mathrm{C}$.

(B) $100^{\circ} \mathrm{C}, \triangle:$ (C) $150^{\circ} \mathrm{C}$,

し，得られたものの物性（混練トルク，引張強度，伸び）を Table 1 に示した.これらの物性と電位差滴定結果を関係付 ける簡単な方法を見い出す目的で, Fig. 1 の滴定曲線で 0.1 $\mathrm{mol} \mathrm{dm}{ }^{-3} \mathrm{HNO}_{3}$ を $0.5 \mathrm{~cm}^{3}$ 滴下した時の $\mathrm{pH}$ 值も Table 1 に示した．水酸化マグネシウムを配合した EEA 物性は， $\mathrm{pH}$ 值に大きく依存した。即ち, $0.1 \mathrm{~mol} \mathrm{dm} \mathrm{dm}^{-3} \mathrm{HNO}_{3}$ を $0.5 \mathrm{~cm}^{3}$ 滴下した時の $\mathrm{pH}$ 值が低いほど（ステアリン酸による有効な 表面被覆の程度が人きいほど)，混練卜ルクが低下して引張 強度や伸び特性が向トした。これは，水酸化マグネシウム粒 子のステアリン酸に上る被㠅率が高くなる上，プラスチック との親和性（分散性）が向上するためであると考えられる.

3. 2.2 表面処理方法とプラスチック破断面に見られる分散 性との関係水酸化マグネシウム試料の EEA 中への分 散性を確認するため，試料（a）（f）をEEAに配合したも のの破断面を SEM 観察した。その中から試料（a），(b)， (d), (f) の写真を Fig. 3 に示す. 試料（a）（未処理）は, 粒子と EEA との馴染みが悪いため粒子の凝集体が見られ， 破断面に数 $10 \mu \mathrm{m}$ の凝集体が観測された。表面処理した試 料（b)，（d）の混練物は，外観は良くなったが，試料（b） （d）のように比較的表面処理量に差がある場合でも（表面処 理量 $\left.5.6 \times 10^{-6}, 9.7 \times 10^{-5} \mathrm{~mol}\right)$, 破断面上で観察された粒 子の分散性に大きな差は見られず, SEM 観察では分散性の 評価は困難であった。なお，写真を示さなかった試料 $(\mathrm{c})$ ， （e）の破断面は，試料（b)，(d）のものと類似していた. 試料（f）の破断面から凝集型粒子の大きな粒子が存在した 形跡が認められ，また，粒子とプラスチックとの親和性が悪 いことも判った。

3. $2.3 \gamma$-MPTMSによる表面処理の効果 Fig. 4 は, $\gamma$-MPTMS で表面処理後, 熱処理温度を変えた試料で得ら れた電位差滴定曲線である。末処理（試料 (A)) に比べ, $\gamma$-MPTMSで表面処理した試料（試料（B)～(E)）は, 3.1 .2 と同様，硝酸滴下による $\mathrm{pH}$ 低下の程度が大きい。ま た, 試料 $(\mathrm{B}) \sim(\mathrm{E})$ は, $\gamma$-MPTMSの表面処理量がほぼ同 じであるが（約 $3.5 \times 10^{-5} \mathrm{~mol} \mathrm{~g}^{-1}$ )，熱処理温度が高くなる ほど，硝酸滴下による $\mathrm{pH}$ 低下の程度はさらに著しくなった。 これは熱処理により, 水酸化マグネシウム表面と $\gamma$ MPTMSとの間でMg-O-Si 結合が形成され，硝酸に対する 反応性が低下したためと考えられる。 
Table 2 Relation between volume resistivity of EEA $\gamma$-MPTMS-coated and heated $\mathrm{Mg}(\mathrm{OH})_{2}$ composites and $\mathrm{pH}$.

\begin{tabular}{c|c|c|c|c|c}
\hline \multicolumn{6}{c}{ Composition: EEA (plasstic) 50 mass $\%, \mathrm{Mg}(\mathrm{OH})_{2} 50$ mass $\%$} \\
\cline { 4 - 5 } Sample & $\begin{array}{c}\text { Heat } \\
\text { treatment } \\
\text { temp. } \\
\left({ }^{\circ} \mathrm{C}\right)\end{array}$ & $\begin{array}{c}\text { Amount of } \\
\gamma \text {-MPTMS } \\
\text { [experimental }] \\
\left(\mathrm{mol} \mathrm{g}^{-1}\right)\end{array}$ & $\begin{array}{c}\text { Before } \\
\text { soaking }\end{array}$ & $\begin{array}{c}\text { After } \\
\text { soaking } \\
\text { in water }\end{array}$ & $\begin{array}{c}\text { Solution } \mathrm{pH} \\
\text { after adding } \\
0.5 \mathrm{~cm}^{3} \text { of } \\
0.1 \mathrm{~mol} \mathrm{dm}^{-3} \\
\mathrm{HNO}_{3} \text { as a } \\
\text { titrant }\end{array}$ \\
\hline (A) & - & 0 & $1.1 \times 10^{14}$ & - & 10.0 \\
\hline (B) & 100 & $3.3 \times 10^{-5}$ & $2.3 \times 10^{14}$ & $1.5 \times 10^{13}$ & 9.3 \\
\hline (C) & 150 & $3.2 \times 10^{-5}$ & $2.5 \times 10^{14}$ & $1.7 \times 10^{13}$ & 9.1 \\
\hline (D) & 200 & $3.7 \times 10^{-5}$ & $3.6 \times 10^{14}$ & $2.3 \times 10^{13}$ & 8.6 \\
\hline (E) & 250 & $3.3 \times 10^{-5}$ & $4.7 \times 10^{14}$ & $4.7 \times 10^{13}$ & 8.5 \\
\hline
\end{tabular}

電位差滴定で評価した上記試料を EEAに溶融混練して得 た混練物について，耐水試験結果と体積抵抗率の水分による 変化，電位差滴定データとの関係を簡単に調べる方法とし て, $0.1 \mathrm{~mol} \mathrm{dm}^{-3}$ 硝酸を $0.5 \mathrm{~cm}^{3}$ 滴下した時の $\mathrm{pH}$ 值との関 係を調べた (Table 2). 体積抵抗率の低下は $\mathrm{Mg}^{2+}$ などのイ オン性物質に起因するので，Mg-O-Si 結合形成反応の進行に より，水分による粒子表面からの $\mathrm{Mg}^{2+}$ の溶出が低減させら れると考えられる。この考えに基づくと，所定量の硝酸滴下 後の溶液 $\mathrm{pH}$ が低くなる水酸化マグネシウム粉末を混練した プラスチックで体積抵抗率が低下しにくくなったと考えられ る.

\section{4 結 言}

疎水化处理剂で表面処理した水酸化マグネシウム粉末の被 覆状態を電位差滴定法で調べ，また，ポリオレフィン系プラ スチックへ混練した場合のプラスチック物性との関係を調ベ た結果，以下の事が判った。

（1）ステアリン酸処理の場合，表面処理量の増加に伴って 電位差滴定での硝酸滴下による $\mathrm{pH}$ 低下の程度が大きく 有効な表面被覆の程度を滴定で判定できることが判っ た.

（2）ステアリン酸处理を湿式法から乾式法にしたり，水酸 化マグネシウム粉末を凝集度の高いものに変えたりす ると, 滴定曲線での $\mathrm{pH}$ 低下の程度は減少し, 有効な表 面被覆ができないことが判明した。

（3）シランカップリング甋（ $\gamma$-MPTMS）処理の場合，湿式 処理物を熱処理したところ温度が高いもの程，硝酸滴 下による $\mathrm{pH}$ 低下の程度は大きく，有効な表面被覆がで きた。
（4）水酸化マグネシウム粉末を配合したプラスチック物性 （混練トルク，引張強度，伸び特性や体積抵抗率）は, 電位差滴定で調べられる処理剤の表面被覆の程度に大 いに依存した，従って，水酸化マグネシウム粉末を配 合したプラスチック物性の評価（分散性や耐水性など） に，電位差滴定法が適用できる。

\section{文 献}

1) 安田武夫, プラスチックス, 50, 18 (1999).

2）相馬 勲, 機能性フィラーの開発技術, CMC, p.221 (2000).

3）英一太，プラスチックの難燃化，日刊上業新聞社，p.101 (1978).

4）曲沢 仁，ポリマーの難燃化，大成社， p.17 (1987).

5）西沢 仁, JETI, 47,109 (1999).

6) 西沢 仁, Polyfile, 4, 52 (1996).

7）フィラーハンドブック，火成社，日本ゴム協会ゴム工業技術 貝会一第 11 分科白色充てん剂特別委員会編，p.156 (1985).

8）フィラー活用事典，大成社，フィラー研究会編，p.264 (1994).

9）カップリング剂最適利用技術，STRL，科学技術総合研究所， p.286 (1988).

10）JIS ハンドブック 11-1，プラスチック試験編，日本規格協会， p.308 (1998).

11）JIS ハンドブック 11-1，プラスチック試験編，日本規格協会, p.219 (1998).

12）宮田茂男，特開昭 52-30262.

13）稲葉恵一，平野二郎，脂肪酸化学，幸書房，第 2 版，p. 58 (1981).

14）稲葉恵一，平野二郎，脂肪酸化学，幸書房，第 2 版，p.49 (1981).

15）朽津耕三，化学便覧 - 基礎編 II, 丸善株式会社, 改定 2 版, p.1407 (1975) 